\title{
The effect of laser on the stimulation of bone-implant interaction: an experimental study in rabbits
}

\author{
Efeito do laser na estimulação da interação osso-implante: \\ um estudo experimental em coelhos
}

\begin{abstract}
Purpose: To assess osseointegration by measuring the removal torque of smooth cylindrical implants placed in rabbit tibiae, having been subjected, or not, to low-intensity laser irradiation (GaAlAs).

Methods: Two implants were inserted into one tibiae of 16 male New Zealand rabbits weighing $3.5-4.0 \mathrm{~kg}$; the animals were divided into four groups (control and laser at 16 and 30 days of wound healing). In the irradiated groups, laser was applied at a 830-nm wavelength, in continuous mode and with $100 \mathrm{~mW}$ of potency, and the applications were punctual, with $1 \mathrm{~J} / \mathrm{cm}^{3}$ on three points, and were repeated eight times at 48 -hour intervals starting immediately after implantation surgery, thus totaling $24 \mathrm{~J} / \mathrm{cm}^{2}$. After the wounds healed, the animals were sacrificed, the tibiae were removed, implant removal torques were measured by means of a handheld digital torque-meter, and a factorial variance analysis statistical test was applied.

Results: There was significant intergroup difference regarding time as a single factor. The removal torque observed in the control groups was, for smooth implants, $20.42 \pm 3.06 \mathrm{~N} / \mathrm{cm}$ at 16 days and $27.42 \pm 19.65 \mathrm{~N} / \mathrm{cm}$ at 30 days; in the irradiated groups, the removal torque for smooth implants was $19.15 \pm 4.65 \mathrm{~N} / \mathrm{cm}$ at 16 days and $30.08 \pm 4.14 \mathrm{~N} / \mathrm{cm}$ at 30 days. Conclusion: Removal torque values were higher at 30 days than at 16 days, independent of laser application.
\end{abstract}

Key words: Laser; implants; osseointegration; removal torque

\section{Resumo}

Objetivo: Avaliar a osseointegração através do torque de remoção de implantes cilíndricos lisos, colocados em tíbias de coelhos, submetidos ou não à irradiação com laser de baixa intensidade (AsGaAl).

Metodologia: Foram utilizados 16 coelhos machos da raça Nova Zelândia, pesando entre 3,5 a 4,0 quilos, sendo inseridos dois implantes em uma tíbia, dividida em quatro grupos (controle e laser para 16 e 30 dias de cicatrização). No grupo irradiado foi aplicado laser com comprimento de onda de $830 \mathrm{~nm}$, modo contínuo e potência de $100 \mathrm{~mW}$, sendo a aplicação pontual de $1 \mathrm{~J} / \mathrm{cm}^{2}$ em três pontos e oito aplicações, com intervalo de 48 horas, iniciada imediatamente após a cirurgia de colocação dos implantes, perfazendo um total de $24 \mathrm{~J} / \mathrm{cm}^{2}$. Após o período de cicatrização, os animais foram sacrificados, e então, realizada a remoção das tíbias e, em seguida, a medição dos torques para remoção dos implantes com torquímetro digital manual, aplicando-se o teste estatístico de Análise de Variância Fatorial.

Resultados: Foi verificado que existe diferença significativa intra-grupos em relação ao fator isolado tempo. O torque de remoção obtido para o grupo controle: Implantes lisos com 16 dias $(20,42 \pm 3,06 \mathrm{~N} / \mathrm{cm})$ e 30 dias $(27,42 \pm 19,65 \mathrm{~N} / \mathrm{cm})$; e para o grupo irradiado: Implantes lisos com 16 dias $(19,15 \pm 4,65 \mathrm{~N} / \mathrm{cm})$ e 30 dias $(30,08 \pm 4,14 \mathrm{~N} / \mathrm{cm})$.

Conclusão: Os valores do torque de remoção no período de 30 dias são superiores ao período de 16 dias, independentemente da aplicação de laser.

Palavras-chave: Laser; implantes; osseointegração; torque de remoção

\author{
Kleber Ricardo Monteiro Meyer a \\ Marco Antonio Rambo Osório a \\ Sabrina Rebollo Zani a \\ Eduardo Rolim Teixeira a
}

- Graduate Program in Dentistry, School of Dentistry, Pontifical Catholic University of Rio Grande do Sul, Porto Alegre, RS, Brazil

\author{
Correspondence: \\ Kleber Meyer \\ Rua Aneron Correa de Oliveira, 47 \\ Porto Alegre, RS - Brasil \\ 91410-070 \\ E-mail:meyer@portoweb.com.br
}

Received: August 29, 2010

Accepted: September 2, 2011

Conflict of Interest Statement: The authors state that there are no financial and personal conflicts of interest that could have inappropriately influenced their work.

Copyright: (C) 2011 Meyer et al.; licensee EDIPUCRS. This is an Open Access article distributed under the terms of the Creative Commons AttributionNoncommercial-No Derivative Works 3.0 Unported License. 


\section{Introduction}

Lasers have been widely used in medicine and dentistry since Maiman developed the ruby laser in 1960. A wide variety of laser types, including helium-neon (HeNe), gallium-aluminum-arsenide (GaAlAs), argon and others, have been used at different doses and for various treatment indications (1).

The notion that low-potency laser might be therapeutic or sufficient to relief pain and promote tissue repair has been the subject of debate among medical scientists and practitioners (2). Some studies have indicated that low-potency lasers, i.e., lasers of 1 to $120 \mathrm{~mW}$ of average potency, promote skin, ligament, nerve, tendon, bone and cartilage repair processes in experimental animal models (3), as well as healing of wounds and ulcers associated in humans with a wide range of causes (4). Other studies have reported the opposite results, i.e., that low-intensity lasers and other monochromatic light sources are ineffective in promoting tissue repair, giving rise to much doubt about their therapeutic application and effectiveness (5).

Studies on laser application associated with dental implant treatment have evolved significantly in recent years, aimed at affording comfort to patients by the use of lasers to reduce postoperative pain and edema (6), to solve postoperative problems such as paresthesia (6) and to treat peri-implantitis (7); more particularly, laser has also been studied as a biostimulator of osseointegration. Pinheiro et al. (8) observed the effect of a laser diode, at $830 \mathrm{~nm}, 40 \mathrm{~mW}$ of potency and a $4.8-\mathrm{J} / \mathrm{cm}^{2}$ dose, on bone repair after implant placement in the tibiae of dogs; their results suggested that laser may improve bone healing at the tissue-implant interface in the early phases of wound healing.

Khandra et al. (9) observed the effect of low-level laser therapy (LLLT) on implant wound healing in an animal study with rabbits by using a GaAlAs diode laser device, and they reported that the results of tensile testing, histomorphometry and X-ray microanalysis showed that LLLT had a positive effect on the functional fixation of titanium implants in bones.

Many researchers and specialists have attempted to accomplish osseointegration in an adequate manner, in shorter clinical time and with consequent optimization of the patient's rehabilitation time. For these reasons, this study is relevant because it aims to assess the osseointegration of implants subjected, or not, to gallium-aluminum-arsenide laser irradiation by measuring smooth-surface cylindrical implant removal torque.

\section{Methods}

\section{Sample}

This study used 16 male New Zealand rabbits (Oryctolagus cuniculus), at the age of three months and weighing 3.5-4.0 $\mathrm{kg}$, that came from the same breeder. The animals were given solid food (Natural Line, Purina ${ }^{\circledR}$, Richmond, VA, USA) and water ad libitum. The animals were randomly distributed into individual suspended cages, which prevented their contact with feces and urine. The cages were supplied by the animal experimentation laboratory of the Rio Grande do Sul state government and were kept under normal light and temperature conditions. Health and weight controls were performed on a daily basis. This study followed the ethical principles for animal experimentation recommended by the Brazilian College of Animal Experimentation (COBEA), and it was approved by the Research Ethics Committee of the Faculty of Dentistry of Pontifical Catholic University of Rio Grande do Sul (PUCRS) and the PUCRS Ethics Committee.

\section{Surgical procedure}

After being weighed, the animals were given anesthetic medication (Zoletil ${ }^{\circledR} 50 \mathrm{mg}$ [zolazepam] and tiletamine, Lab. Virbac S.A. - France) in a $5-\mathrm{mg} / \mathrm{kg}$ dose by intramuscular route (disposable sterile syringe and needle - B.D. ${ }^{\circledR}$, São Paulo, Brazil). Ten minutes later, a trichotomy was performed on the animals, already under general anesthesia, at the surgical site by means of a rechargeable clipper (Oster®, São Paulo, Brazil). This was immediately followed by asepsis with 70\% alcohol and the use of an NWT (non-woven

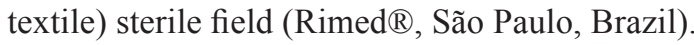

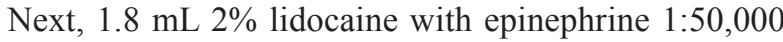
(DFL ${ }^{\circledR}$, Rio de Janeiro, Brazil) was injected into the incision site, which was created by means of a sterile no. 15 blade scalpel (Paramount ${ }^{\circ}$, New Delhi, India) over $3.0 \mathrm{~cm}$ on the rear limbs, involving the skin and the tissues below (connnective tissue and periosteum) up to the bone surface. Muscular tissue and the periosteum were divulsed and kept apart by means of a no. 7 spatula. After bone exposure, drilling was performed to place smooth-surface titanium implants, which were $3.75 \mathrm{~mm}$ in diameter and $5 \mathrm{~mm}$ in length (Conexão Sistemas de Prótese, São Paulo, SP, Brazil).

The full drilling sequence was performed at a velocity of $900 \mathrm{rpm}$ (rotations per minute) by means of an engine (Driller ${ }^{\circledR}$ Blm 600, São Paulo, Brazil) with a 16:1 counterangle reducer (Kavo ${ }^{\circledR}$, Joinvile, SC, Brazil) and with liberal irrigation of $0.9 \%$ saline solution (Labormédica ${ }^{\circledR}$, Pouso Alegre, MG, Brazil) to avoid bone superheating. The implants were inserted and exhibited $35 \mathrm{~N} / \mathrm{cm}$ of primary stability.

Next, the peritoneum was replaced and sutured together with muscular and skin tissue using a 3-0 nylon thread (Tech Synth ${ }^{\circledR}$, Bangalore, India). After suturing, the skin over the implants was painted with $1 \%$ gentian violet (INDAFARMA $^{\circledR}$, São Paulo, Brazil) to identify the three laser irradiation points next to the implants. All animals received antibiotic treatment by means of Pentabiotic (penicillin and streptomycin 20,000 IU) by intramuscular route (Lab. Forte Dogde Ltda, Campinas, SP, Brazil) for five days, in addition to Rifocina spray ${ }^{\circledR}\left(\right.$ Eurofarma $^{\circledR}$, Santo Amaro, SP, Brazil) at the incision site over the sutures, also for five days. To control pain, the animals were given the analgesic/anti-inflammatory agent Alivium ${ }^{\circledR}$ in drops 
(ibuprofen 100 mg/mL; Mantecorp Ind. Ltda, Rio de Janeiro, Brazil); 20 drops were added daily to the drinking water for five days. The sutures were removed seven days later in all groups of animals.

Medication, feeding, weight and the health state of the animals were controlled on a daily basis after surgery by a veterinary doctor.

\section{Laser treatment}

The laser used was a diode device, which was a semiconductor with a GaAlAs active medium (DMC $\AA$; Photon Laser III model, São Carlos, SP, Brazil), infrared with a 830-nm wavelength, continuous emission and $1 \mathrm{~J} / \mathrm{cm}^{2}$ of energy density (beam potency: $100 \mathrm{~mW}$ ), with punctual application and a ten-second application time. Irradiated animals were given transcutaneous irradiation at three points close to the implants, every 48 hours for 15 days; the first application was performed on the same day as surgery, for a total of eight irradiation days at $3 \mathrm{~J} / \mathrm{cm}^{2}$ per application, and thus, the total dose was $24 \mathrm{~J} / \mathrm{cm}^{2}$ ( 3 points $\times 1 \mathrm{~J}$ x 8 applications $=24 \mathrm{~J})$. Non-irradiated animals were subjected to false irradiation and the same routine as the irradiated animals.

The calculation of the used dose was as follows (6):

$$
\text { Dose }\left(\mathrm{J} / \mathrm{cm}^{2}\right)=\operatorname{PD}\left(\mathrm{W} / \mathrm{cm}^{2}\right) \times \text { laser time }(\mathrm{s}),
$$

where $\mathrm{PD}=$ potency $(\mathrm{W}) /$ spot size $\left(\mathrm{cm}^{2}\right)$

$$
\mathrm{PD}=100 \mathrm{~mW}=0.1 \mathrm{~W} / 1 \mathrm{~cm}^{2}=0.1 \mathrm{~W} / \mathrm{cm}^{2}
$$$$
\text { Dose }=0.1 \mathrm{~W} / \mathrm{cm}^{2} \times 10 \mathrm{~s}=1 \mathrm{~J} / \mathrm{cm}^{2}
$$

\section{Tensile test}

After 16 days of implant placement in groups 1 and 2 and after 30 days in groups 3 and 4, the animals were sacrificed by carbon dioxide inhalation, following the vivarium protocol and the recommendations for animal vivisection in scientific didactic practice.

Next, the specimens were removed; an incision was performed with a no. 15 blade scalpel at the tibiae's upper and lower joints, and this segment was separated from the remainder of the limb; all soft tissues were removed, and only the bone bearing the visible implants was kept. Two rabbits were lost: they were sacrificed on the second day after surgery due to bone fractures in the same leg. One of these rabbits had also begun self-mutilating; therefore, it was also sacrificed by following the same protocol.
For osseointegration assessment, a TSD 150 model handheld digital torque-meter (Torqueleder-MHH Engineering Co. Ltd., Bramley, Guilford, Surrey GU5 OAJ, UK) was used, which provided peak readings and thus facilitated the measurement of implant tightening and untightening torque. The bone segments containing the implants were secured by their lower ends in a vise fixed to a workbench, which was distant from the implant sites. Next, the implant protection covers and mount connections were removed. A steel device was used to link the mounts to the torque-meter, to measure the implant removal torque by means of anti-rotational motion. The implants were placed perpendicular to the ground, and the torque-meter was kept along the implant axis to perform the measurements. Its reading module was set at the peak-reading mode; thus, only the maximum value attained by removal torque was recorded. The values were measured in $\mathrm{N} / \mathrm{cm}$ and corresponded to the moment when the implant-bone union was broken. All measurements were performed by the same blinded researcher. A total of 32 implants were placed in 16 rabbits, of which 26 were used because four were lost when two rabbits were sacrificed and one was rated non-osseointegrated; thus, the corresponding rabbit was excluded from the study.

\section{Statistical analysis}

Student's t test was applied to tensile measurement results to calculate means and standard deviations in all groups. Factorial variance analysis was used to compare results among the groups (irradiated and control). Significance was established at $5 \%$. To process and analyze the data, SPSS statistical software, version 10.0, was used.

\section{Results}

Wound-healing time was the highest-value determinant factor in removal torque, independent of laser application. Verification was performed by means of Student's t test and a factorial variance analysis test aimed at establishing not only each separate factor (group, implant and time) but also the interactions among them.

Data regarding 16-day wound-healing time were gathered from implants in the control $(20.42 \mathrm{~N} / \mathrm{cm})$ and laser $(19.15$ $\mathrm{N} / \mathrm{cm}$ ) groups. For 30-day wound-healing time, the highest values were exhibited by implants associated with laser application $(30.08 \mathrm{~N} / \mathrm{cm})$, compared to the control group $(27.42 \mathrm{~N} / \mathrm{cm})$, as shown in Table 1 .
Table 1. Descriptive results of group-time interactions.

\begin{tabular}{cccccc}
\hline Group & Implant & Time & $\mathbf{n}$ & Mean* & Standard deviation \\
\hline Control & Smooth & 16 days & 5 & 20.42 & 3.06 \\
& & 30 days & 7 & 27.42 & 19.65 \\
\multirow{3}{*}{ Laser } & Smooth & 16 days & 8 & 19.15 & 4.65 \\
& & 30 days & 6 & 30.08 & 4.14 \\
\hline
\end{tabular}

* Student's + test. 


\section{Discussion}

The irradiation protocol in this study was established according to the specialized literature $(5,9)$, which states that the methods must agree with the type of laser chosen for the target tissue, which can be reproduced by defining the wavelength, application time and mode, time interval, dose and laser type $(10,11)$.

Pinheiro et al. (8) showed by means of MEV assessment that the influence of laser on bone regeneration around implants reached as deep as $6 \mathrm{~mm}$ with an infrared diode laser at $830 \mathrm{~nm}$. The energy dose used in this study agreed with most published studies, which state that the optimal dose is $3 \mathrm{~J} / \mathrm{cm}^{2}(2)$, inferring that most biological responses to low-potency laser occur with doses of 1.0 to $10 \mathrm{~J} / \mathrm{cm}^{2}$. According to Khandra (12), LLLT accomplished with a dose ranging from 1.5 to $3 \mathrm{~J} / \mathrm{cm}^{2}$ may modulate the activity of cells interacting with an implant and thus improve tissue healing and the odds of success of definitive implants. This author stated that the response was better with multiple applications, compared to a single application of the total dose. The application time and number used in this study agreed with other studies $(13,14)$, in which laser applications were multiple, every 48 hours for 15 days; multiple applications achieve better results than one single dose.

The bone quality of rabbits has been established to be more adequate for longer wound-healing times when assessing bone neoformations, because rabbit bone's cortex is extremely calcified, and there is no bone trabecullae in the medullar area. Results have shown that in the early stages, this newly formed bone exhibits too little resistance to induce differences in torque measurement; this finding agrees with Ivanoff et al. (15), while stressing that it is cortical bone that supports implants, even after 12 weeks in studies performed with rabbits. In this animal model, the measurements of implants seemed different when placed closer to the joint, in which the medullar area was greater than with implants placed farther from the joint, which exhibited a smaller medullar area. Thus, when implants were close to the lateral cortex, they possibly facilitated bone growth toward implants.

This study's results were less expressive compared to other studies, and they contradicted the literature showing that the differential effect of laser application occurs at the early stage of wound healing $(3,8,10,14)$. Time factors associated with laser application and the use of smooth surface implants resulted in better fixation of implants. This fact is extremely important and demonstrates a positive, differential effect in machined implant retention.

Regarding qualitative assessment of rabbits in the early postoperative period, it is worth observing that animals in the laser groups showed better recovery and less discomfort than the control groups, as well as healthier feeding and better soft tissue healing appearance. This assessment was not the aim of this study; however, it was a part of the bioethical control of the experimental animals' health and comfort and thus supports the literature reporting on analgesic laser and its anti-inflammatory effects $(3,5,16,17)$.

On the basis of these results, we suggest that further longitudinal and controlled studies be performed to understand better the actual association between local laser application and dental implants' osseointegration responses.

\section{Conclusions}

Wound-healing time was the factor most influencing significant increases in removal torque among the factors investigated, because at 30 days of wound healing, the results showed higher values compared to the measurements at 16 days. Laser application was able to alter significantly smooth implant removal torque at 30 days, as shown by the significant differences among the observed results.

Referências 1. Pinheiro AL, Brugnera AJ. Laser odontol. Mod. São Paulo: Pancast, 1998.

2. Reddy GK. Photobiological Basis and Clinical Role of Low- Intensity Lasers in Biology and Medicine. J Clin Laser Med Surg 2004;22:141-50.

3. Garcia VG, Carvalho PS, Oliveira JA. Ação da Radiação Laser. RGO 1995;43:191-4.

4. Moreira LA, Santos MT, Campos VF, Genovese WJ. Efficiency of Laser Therapy Applied in Labial Traumatism of Patients with Spastic Cerebral Palsy. Braz Dent J 2004;15: 29-33.

5. Karu TI. Photobiology fundamentals of low-power laser therapy. IEEE J Quantum Electron 1987; 10:1703-17

6. Mello JB, Mello GPS. Laser em Odontologia. São Paulo: Santos; 2001.

7. Deppe H, Greim H, Brill T. Titanium deposition after peri-implant care with the carbon dioxide laser. Int J Oral Maxillofac Implants 2002;17:707-14.

8. Pinheiro AL, Oliveira MG, Martins PP, Ramalho LM, Oliveira MA, Silva Júnior AN, et al. Biomodulation effects of LLLT on bone regeneration. Laser Ther 2001;13:73-9.

9. Khadra M, Ronold HJ, Lyngstadaas SP, Ellingsen JE, Haanxs HR. Low-level laser therapy stimulates bone-implant interaction: an experimental study in rabbits. Clin Oral Implants Res 2004; 15:325-32. 
10. Campanha BP. Luz polarizada (1400-2000nm) e laser não-ablativo (1685nm): descrição do processo de reparo em feridas, através de avaliação morfológica e imunohistoquímica [dissertação]. Porto Alegre (RS): Pontifícia Universidade Católica do Rio Grande do Sul, 2002.

11. Dörtbudak O, Haas R, Mailath-Pokporny G. Biostimulation of bone marrow cells with a diode soft laser. Clin Oral Implants Res 2000;1 1:540-45.

12. Khadra M. The effect of low level laser irradiation on implant-tissue interation. In vivo and vitro studies. Swed Dent J Suppl 2005;172:1-63.

13. Lopes CB. Biomodulação laser em implantes ósseos: um estudo com Espectroscopia Raman [dissertação]. São José dos Campos (SP): Universidade do Vale do Paraíba, 2002.

14. Pinheiro AL, Limeira Júnior FA, Gerbi ME, Ramalho LM, Marzola C, Ponzi EA, et al. Effect of 830-nm Laser Light on the Repair of Bone Defects Grafted with Inorganic Bovine Bone and Decalcified Cortical Osseus Membrane. J Clin Laser Med Surg 2003;21:301-06.

15. Ivanoff CJ, Sennerby L, Johansson C, Rangert B, Lekholm U. Influence of implant diameters on the integration of screw implants: An experimental study in rabbits. Int J Oral Maxillofac Surg 1997;26:141-48.

16. Dörtbudak O, Hass R, Mailath-Pokorny G. Effect of low-power laser irradiation on bone implants sites. Clin Oral Implants Res 2002;13:288-92.

17. Genovese WJ. Laser de Baixa Intensidade. Aplicações terapêuticas em Odontologia. São Paulo: Lovisa; 2000. 